\title{
Action Research in Action: From University to School Classrooms
}

\author{
Maja Miskovic, ${ }^{1,2}$ Efrat Sara Efron, ${ }^{1}$ and Ruth Ravid ${ }^{1}$ \\ ${ }^{1}$ National Louis University, Chicago, IL 60603, USA \\ ${ }^{2}$ Department of Educational Foundations, Technology \& Inquiry, National Louis University, 122 S. Michigan Avenue, Chicago, IL \\ 60603, USA \\ Correspondence should be addressed to Maja Miskovic, maja.miskovic@nl.edu
}

Received 5 March 2012; Accepted 15 May 2012

Academic Editor: Gwo-Jen Hwang

Copyright () 2012 Maja Miskovic et al. This is an open access article distributed under the Creative Commons Attribution License, which permits unrestricted use, distribution, and reproduction in any medium, provided the original work is properly cited.

This multiyear mixed-method study was conducted to understand (a) the perceptions of the preservice and in-service teachers regarding the significance of action research in their teaching career and (b) how teachers draw on skills developed in the research courses as they initiate a reflective inquiry and conduct research in their own classrooms. Based on 176 surveys, we conclude that research plays an important role in the teachers' professional life and that teachers desire (a) to have more time to do research, and (b) collaboration with and assistance from colleagues and administrators. Ethnographic data from three participants revealed that each understood research differently, which affected what was unfolding in the classrooms. Implications for teacher research are discussed.

\section{Introduction}

Research courses are required of all preservice (MAT) and in-service (MEd) graduate students in our college of education. These courses present the cycle and process of practitioner research using both qualitative and quantitative methods. Our students acquire the skills to plan, conduct, evaluate, and disseminate practitioner research projects and conduct their own small-scale research studies, considering the issues of ethics, validity (trustworthiness), and reliability (transferability). Although in teaching graduate research courses we encourage our students to become practitioner researchers, until now we have not systematically followed up our students and have not explored their attitudes and whether they actually use in their practice the research skills and knowledge they had obtained in the research courses. In order to examine these questions, we conducted a multiyear, mixed-methods study. This paper presents the research process and the discussion of the results we obtained.

The terms action research and practitioner research are used interchangeably in this paper, as action research is used by practitioners who want to investigate and improve their practice [1]. In their seminal work, over 25 years ago, Carr and Kemmis [2] saw improvement as three-fold: the improvement of a practice, the improvement of the understanding of that practice, and the improvement of the situation in which the practice takes place. Johnson [3] defines action research as "a systematic inquiry into one's own practice" (page xi), while Mertler [4] adds that action research is done by teachers for themselves (page 4). In discussing classroom action research, Kemmis and McTaggart [5] give primacy to teachers' self-understanding: "The emphasis is "practical," that is, on the interpretations that teachers and students are making and acting on in the situation" (page 274). Holly et al. [6] argue that action research offers educators "a powerful tool for transforming the educational environment and what takes place under the auspices of the school" (page 5).

The first part of the paper reviews the literature related to practitioner research and its implications for everyday classroom practices of the teachers who use it. The second part addresses the methodological choice for a mixed method design. We conclude our paper with the discussion of our findings.

\section{Purpose of the Study}

The research questions we asked, the sampling decisions that we made, and the analytical and interpretive strategies 
that we used reflected the assumptions of both quantitative and qualitative methodologies. In the first phase of the study, we surveyed our university's then current and close to graduation students in order to discover their perceptions of the significance of action research in their teaching career. The survey was exploratory, addressing the question: what are the perceptions and opinions of our pre-service and in-service students about the value and usefulness of the research courses sequence at our university?

The purpose of the second phase was to build upon the first phase and understand how the pre-service and in-service teachers draw on skills developed in the research courses as they initiate a reflective inquiry and conduct research in their own classrooms. The second phase was guided by the following questions: (a) How do the teachers view themselves as practitioner researchers? (b) How do they understand the relationship between their teaching and research? (c) What research strategies do these teachers employ in their classrooms? and (d) What are the teachers' concerns and what could be done to support their efforts?

\section{Related Literature}

Action research and other forms of practitioner research (e.g., teacher research and self-study) resemble "a large family, one in which beliefs and relationships vary greatly" ([7], page 306). Common to all the different interpretations is the perception of the teacher's role as a generator of knowledge and as an active agent in the classroom and in the larger educational setting [8]. The literature that documents the work of teachers as researchers is extensive (e.g., [4, 6, 9-13]). This literature highlights the positive effects of practitioner research on novice and veteran educators as it furthers their personal and professional development and enhances their own understanding and competencies. Researching their own practice helps educators face challenging situations and contributes to their ability to understand and solve problems.

The key dimension of the practitioner inquiry's success is the respect for the educator's knowledge and the educator's voice [14]. Connelly and Clandinin [15] call for recentering the teacher's voice through inquiry. Sharing the similar epistemological stance with action research, narratives could propel shifts in teachers' stories about themselves and their practice in that they begin seeing themselves as researchers [16]. Cochran-Smith and Lytle [8] propose the construct "inquiry as stance" that reflects the respect for practitioner research and for the theories generated by teachers in cultural settings of inquiry and widens the teacher's role to include school leadership, decision-making, and policy enactment. The "inquiry as stance" implies the value of practitioner research across the educator's professional lifespan, as preservice experienced teachers pose questions, challenge common routine and generate theories from self and others' experiences.

Still, only a handful of studies were conducted on practitioner research in the context of pre-service education and its meaning for student teachers [12, 17-19]. This is surprising, since action research supports the transition of novice teachers from university study into their profession as it allows them to form their professional identity as educators [12]. As pre-service students become teachers through inquiry, they gradually engender reflective practice and gain a sense of empowerment. Though historically action research has had emancipatory implications, Zeichner and Gore [20] caution teacher educators against developing unrealistic expectations from teacher candidates that are engaged in research in their pre-service studies. According to Price and Valli [18], "Not only are they in a relatively powerless position to effect change within their school contexts, but as novices they often have difficulties even thinking of themselves as teachers, much less as change agents" (page 58). These challenges are accompanied by a neoliberal pressure on schools, where action research is coopted as a technique for the implementation of government policies and a tool to promote particular teaching practices [21]. Still, Price and Valli notice that research courses strongly influence future teachers' expectations of self, of students, of peers, and of educational institutions. Student teachers begin to consider possibilities, challenge taken-for-granted assumptions, and imagine change and improvement.

The commitment of teachers to engage in practitioner research is not without problems. Critics (e.g., [22-24]) question the validity of practitioner inquiry and feel that teachers lack sufficient research skills and do not trust their ability to collect and interpret data. In addition, we need to investigate what are the conditions that facilitate or obstruct the disposition and ability of educators to research their own practice and how to reduce the inherent tensions between teaching and researching [14]. Some teachers, especially beginner teachers, find themselves overwhelmed by the demands of their work and feel that they do not have the time to be involved with an inquiry that seems to be an additional, unnecessary activity [8]. They may also not feel comfortable in looking critically at the educational conditions of the school or challenging established assumptions $[25,26]$.

Moreover, it is not clear how much the school systems truly support practitioner research or where they view it among competing school priorities. Whereas in the early 1990 s teacher research was aligned with the teacher professionalization movement and called for an enlarged teacher role and responsibility, in the current era of educational standards and accountability we face attempts to deskill teachers and dismiss their roles as coconstructors of knowledge [8]. We are now, in the second decade of the 21st century, again, as in the 1980s, facing an environment in which "none of the conditions which support and sustain investigationtime, facilities, preparation, ethos, or reward structureexist in public schools" ([27], page 5). Referring back to his seminal Becoming Critical, Kemmis [28] lamented the lost hope of action research that could "seize the possibilities for education in the communicative spaces that open each day in the interstices of schooling" (page 669). Instead, action research has lost its critical edge and become work that teachers do in the privacy of their classrooms. We concur with Kemmis' notion that action research has a double task of the "development of individual persons and the development of good societies and the good for the human 
kind" (page 468). The latter premise has yet to happen, so that teachers would feel supported and rewarded by the society that would, in turn, put trust into teachers as creators of just societies.

\section{Methodology}

4.1. Sample. 176 students who had completed the research sequence filled out the survey. The sample included 79 (45\%) pre-service (MAT) and 97 (55\%) in-service (MEd) students who either graduated recently or planed to graduate in the next two years. One hundred twenty-six $(72 \%)$ of the respondents were teaching at the time, 16 (9\%) had taught in the past, and $34(19 \%)$ had no teaching experience. An overwhelming majority of those who taught at the time or had taught in the past have been teaching in suburban schools. Those with teaching experience reported teaching all grade levels and all subjects.

We then contacted via e-mail students who had been enrolled in our classes and completed the survey. The best description of our sampling strategy would be purposeful intensity sampling [29]. Our goal was not to test or "check" if the students applied the principles of action research in their classrooms, rather, we focused on those students who during their coursework expressed interest in action research through engaged readings of the assigned texts and who via their assignments demonstrated a mindful application of what was read and discussed in class. We wanted to collaborate with our students as researcher partners rather than to act as their former classroom instructors. We invited them to "participate actively with the professional researchers throughout the research process from the initial design to the final presentation of results and discussion of their action implementations" (Whyte et al., cited in [30], page 116) . In our e-mail message, we explained the purpose of our research and asked the students to respond if they wished to participate in the study. Only one student initially responded positively. We then approached the students personally in our fall and winter classes. Quite a few were teaching at that point and were worried about taking on additional responsibility, as the collaboration in the research process probably looked like an extended workload. Finally, after prolonged conversations and deliberations that lasted for almost three months, our sample was finalized; it consisted of three teachers who volunteered and were in the process of earning a Master degree: two in a preservice program and one in an in-service program. Two participants were females and one male. Scott (All the names are pseudonyms.) is a white male in his 40 s for whom teaching is the second career. Most of his work experience prior to completing his MAT degree was in non-for-profit organizations in which he was involved with fundraising and political action. At the time of this research, Scott taught a self-contained classroom of seventh- and eighth-grade students with learning and behavioral disorders.

Wendy is a white female in her 30s. She teaches language, arts, and math to 5 sixth-grade classes in a suburban middle school. Wendy and her former professor collaborated on a research project and mutually chose the topic of homework. They created, administered, and analyzed together the results from the survey which was designed to measure Wendy's students' attitudes toward homework.

Ana is a fourth-year special education teacher in a Chicago suburban middle school. A white woman in her late 20s, her goal in this project was to become culturally responsive teacher to her mostly African American male students. She understood research process as educating herself further about the specific needs of her students and helping them negotiate the complex interplay of race, gender, and academic achievement. Ana and her former professor had multiple conversations after the observations of classroom dynamics: for the instructor these occasions were a place to clarify field notes and for Ana to actively reflect on the teaching process and find ways to understand her own and her students' words and actions.

\subsection{Data Collection}

4.2.1. Surveys. We constructed a survey that was administered in the first phase of the study. Part 1 of the survey included seven Likert-scale items and was designed to explore how respondents view the role of practitioner research in the context of their educational practice and what may be some factors that can contribute to or deter teachers from conducting action research. Each item included a statement with response choices that ranged from Strongly Agree (4 points) to Strongly Disagree (1 point). Following each statement, respondents were asked to explain their numerical response. Sample questions are as follow: "I believe that conducting practitioner research is part of being an effective teacher" and "I believe that the main barrier to conducting teacher research is a lack of time." Part 2 of the survey listed 8 research skills and competencies that are emphasized in the research courses sequence. Respondents were asked to indicate how competent they felt in using each of the skills to study their practice. The response scale included four choices ranging from Very Competent (4 points) to Not Competent (1 point). Sample questions are as follow: "I can identify and pose research questions" and "I can design appropriate data collection tools." The last section gathered demographic information about the students' degree program, date of graduation, research courses taken, and teaching experience. While we did not assess the scale's reliability, the content validity was assessed by pilot testing the survey with students in the classes we thought.

4.2.2. Ethnographic Data. The centerpiece of the qualitative phase was an ethnographic approach, with interviews and unstructured observations of teachers in their natural setting in order to investigate how they understand and apply research practices in their own classrooms. This phase of the study started in the fall of 2006 and lasted until July 2007. As a crucial part of ethnographic tradition, observation is particularly useful in attempts to place specific interactions, events, and people into a meaningful context [31]. When visiting the classrooms, we intentionally and frequently 
TABLE 1: Rank orders by means, and standard deviations of the responses to the attitude items (questions $1-7)$ for all respondents $(N=176)$.

\begin{tabular}{|c|c|c|c|}
\hline Rank & Question & Mean & SD \\
\hline 1 & Q4: I believe that the main barrier to conducting teacher research is a lack of time & 3.43 & 0.737 \\
\hline 2 & Q7: It is more likely that I would conduct practitioner research if I could collaborate with others & 3.21 & 0.812 \\
\hline 3 & Q1: I believe that conducting practitioner research is part of being an effective teacher & 3.18 & 0.606 \\
\hline 4 & $\begin{array}{l}\text { Q5: I believe that I would be able to conduct practitioner research if my administrators were to provide me with } \\
\text { the proper support }\end{array}$ & 3.07 & 0.727 \\
\hline 5 & $\begin{array}{l}\text { Q2: I believe that most of what I have learned in the research course sequence would help me reflect on my } \\
\text { educational practice and become a better teacher }\end{array}$ & 3.03 & 0.723 \\
\hline 6 & Q6: I believe I can conduct practitioner research if my colleagues were supportive of me & 2.95 & 0.732 \\
\hline 7 & $\begin{array}{l}\text { Q3: As a result of having taken the research courses at NLU, I can now better understand and reflect on my } \\
\text { students' behavior and performance }\end{array}$ & 2.94 & 0.731 \\
\hline
\end{tabular}

shifted our schedule in order to see different dynamics at the beginning, middle, and end of the day or week. The observations were accompanied by individual and focus group interviews of the three teachers who participated in this phase of the study. Individual interviews-formal and informal, semistructured and open-were conducted during the nine month period. We accumulated between 30 and 60 hours of observation and 2 to 4 hours of recorded interviews.

Focus group interview enhanced our process of data collection in that the teachers had an opportunity not only to inform us of their research practices but each other as well. Therefore, this was not only a research but pedagogical site as well [32]. In addition, the three researchers and teacher participants communicated regularly via e-mail. These communications included teachers' journal narratives, describing events that took place on particular days, personal reflections, frustrations, successes, and moments of selfquestioning about the goals, expectations, and direction in their teaching.

\subsection{Data Analysis}

4.3.1. Quantitative Analysis. Using SPSS for Windows, survey item means were generated to rank order the attitudinal and competency items for all respondents. In addition, a series of $t$-tests were conducted to compare the responses to the attitudinal and competency items by program (MAT versus MEd). The means and standard deviations of the appropriate total group of respondents were used to compute the effect sizes.

4.3.2. Qualitative Analysis. Analysis and interpretation of qualitative data addressed "the identification of essential features and the systematic description of interrelationships among them-in short how things work" ([33] page 12). We drew our conclusions from the analysis using the strategies of comparing, contrasting, finding commonalities and differences, noting the patterns and themes, and looking for negative cases. We also followed the principles stated by Wolcott [33]: (1) highlighting the findings: the data were reduced by data summaries, finding themes, and patterns, and writing the text of the research findings; (2) displaying the findings: after reducing the data, a choice was made as to which data to display by using interview and observation vignettes and interpretative summaries. This step allows others to see the way the researchers draw their conclusions.

To enhance the trustworthiness of the qualitative phase of the study [34, 35], we spent a prolonged time in participants' classrooms and engaged in persistent observations in order to learn more about the classroom culture and dynamics when teacher research occurred. We used multiple data collection methods and shared our interview transcripts and preliminary data analysis with the participants.

\section{Results and Discussion}

5.1. Quantitative Results. The first analysis was of the mean responses of all students to the attitudinal items (see Table 1). The table provides a rank order of the items based on their means as well as the items' standard deviations. In general, the respondents agreed or strongly agreed with the seven attitude items.

The highest agreement among the respondents was to item 4, which stated that the main barrier to conducting teacher research is a lack of time (a mean of 3.43 on a 4-point scale). Respondents also agreed that conducting practitioner research is part of being an effective teacher (mean of 3.18; item 1) and that they would be more likely to conduct practitioner research if they could collaborate with others and get support from their administrators and colleagues (items 7, 5, and 6). In addition, the respondents agreed that the research courses that they took at our university would help them reflect on their practice and students and become better teachers (items 6 and 3). We were also interested to find out what research competencies teachers believed were gained during the graduate classes they took. Table 2 shows the mean responses of the whole group to the competency items.

The means ranged from 2.70 (item 11) to 3.15 (item $8)$. These results indicate that the students felt between somewhat competent ( 2 points) and competent ( 3 points) on all the research competencies and skills listed in the survey. Students reported feeling most competent in identifying and posing research questions (item 8). Their responses to items $15,9,13$, and 14 ranged from 2.98 to 2.91 , indicating that the students felt competent in relation to these skills and 
TABLE 2: Rank orders by means, and standard deviations of the responses to the competency items for all respondents $(N=176)$.

\begin{tabular}{llll}
\hline Rank & Question & Mean & SD \\
\hline 1 & Q8: I can identify and pose research questions & 3.15 & 0.680 \\
2 & Q15: I can describe the study and its findings in an oral or written report & 2.98 & 2.93 \\
3 & Q9: I can review and synthesize existing research & 2.91 & 0.760 \\
4 & Q13: I can organize and analyze the data I collected & 2.91 & 0.771 \\
5 & Q14: I can interpret the findings from the data I collect & 2.81 & 0.830 \\
6 & Q12: I can select existing data collection tools, when available & 2.73 & 0.801 \\
7 & Q10: I can plan a research study & 2.70 \\
8 & Q11: I can design appropriate data collection tools & 0.719 \\
\hline
\end{tabular}

competencies. These skills included the ability to review and synthesize existing literature on a topic of interest, analyze and interpret data they collected, and report on their study. Students were somewhat less sure about their ability to plan research studies (item 10; mean of 2.73) and design appropriate data collection tools (item 11; mean of 2.70).

To compare the responses of preservice students in our MAT programs $(N=79)$ to those in the in-service MEd programs $(N=97)$, we performed a series of $t$-tests for independent samples. Table 3 shows the results for the attitudinal items.

The means of the two groups were very similar on items 2-7. The largest difference was between the two groups on item 1 where practicing teachers had a higher level of agreement with the statement "I believe that practitioner research is part of being an effective teacher." This difference was statistically significant at $P=.004$. Following the guidelines suggested by Cohen [36], the effect size for this items is considered low-to-moderate $(\mathrm{ES}=.429)$. The effect sizes for all other items were low to very low and ranged from -0.069 (item 2) to 0.190 (item 4).

The responses to the competency items of the students in the two programs are presented in Table 4. Once again, the responses of the two groups were very similar, even though in all but one item (item 10) the MAT students had a slightly higher mean than the MEd students. The small differences between the groups were not statistically significant.

Although not surprising, our survey confirmed what many practitioners already know: students see a lack of time as the main barrier to doing research (item 4). This finding confirms those reported by Cochran-Smith and Lytle [8] who found that beginner teachers are overwhelmed by the demands of their work and feel that they do not have the time to engage in inquiry which they do not see as necessary for their job. The respondents also asserted that they would be more likely and able to conduct research if they could collaborate with others (item 7) and gain the support of their administrators (item 5) and colleagues (item 6). We were gratified to see that the respondents see action research as part of being effective teachers (item 1). The respondents also reported that the research courses that they took at our university enhanced their ability to conduct research and become better teachers (item 2 and 3 ).

A comparison of students' responses by program showed that in-service teachers had a somewhat more positive attitude toward action research than pre-service teachers. They also were more open to research and saw its relevancy and potential application to their practice. The biggest difference between the two groups was on item 1 which stated "I believe practitioner research is part of being an effective teacher." MEd students had a higher mean on this item which may indicate that practicing teachers can better see the relevancy of action research to their practice. Our experiences in teaching pre-service teachers indicate that many of them are more often concerned with issues of classroom management and lesson planning and may not see as easily as practicing teachers the relationship between being an effective teacher and doing action research. MEd students also responded more positively to item 2 which stated "The research courses would help me become a better teacher." However, it should be mentioned that the mean response of pre-service students to these two items was also high, around 3.00 (i.e., agree). In general, MEd students were more open to action research and saw its relevancy and potential application to their practice.

5.2. Qualitative Results. When three of our students indicated their agreement to participate in the study, it became apparent that they had different reasons for wanting to participate in the action research projects, and this fact shaped the nature of our collaboration. The qualitative phase of our study explored what was happening in the classrooms for those teachers who already used research principles or attempted to do so and saw the collaboration with us as the step in that direction. There are multiple ways and approaches to action research, which can be designed and implemented by the partners to fit their needs, interests, and schedules. The results of our study show how different contexts and interests produced different ways of understanding and doing research. The next section represents the major themes we identified in the process of data analysis and interpretation and reflects different experiences and settings under which the research process was unfolding.

5.3. Action Research as a Mentoring Process. Mills argued that "every man [is] his own methodologist" ([37], page 123). The practical aspects of action research, Scott's needs and the problems he faced, prescribed the inquiry methods 
TABLE 3: Comparison of students' responses to the attitude questions broken down by degree program (MAT: $N=79 ; \mathrm{MEd}: N=97)$.

\begin{tabular}{|c|c|c|c|c|c|c|}
\hline Question & Program & Mean & $\mathrm{SD}$ & $t$ value & $P$ value & ES \\
\hline \multirow{2}{*}{ Q1: PR is part of being an effective teacher } & MAT & 3.04 & 0.669 & \multirow{2}{*}{-2.903} & \multirow{2}{*}{.004} & \multirow{2}{*}{-0.429} \\
\hline & MEd & 3.30 & 0.524 & & & \\
\hline \multirow{2}{*}{ Q2: The research courses would help me become a better teacher } & MAT & 3.00 & 0.739 & \multirow{2}{*}{-0.468} & \multirow{2}{*}{.640} & \multirow{2}{*}{-0.069} \\
\hline & MEd & 3.05 & 0.713 & & & \\
\hline \multirow{2}{*}{$\begin{array}{l}\text { Q3: The research courses would help me better understand my students' } \\
\text { performance }\end{array}$} & MAT & 2.87 & 0.789 & \multirow{2}{*}{-1.173} & \multirow{2}{*}{.242} & \multirow{2}{*}{-0.178} \\
\hline & MEd & 3.00 & 0.681 & & & \\
\hline \multirow{2}{*}{ Q4: The main barrier to teacher research is a lack of time } & MAT & 3.35 & 0.785 & \multirow{2}{*}{-1.258} & \multirow{2}{*}{.210} & \multirow{2}{*}{-0.190} \\
\hline & MEd & 3.49 & 0.694 & & & \\
\hline \multirow{2}{*}{ Q5: The proper support from administrators would help me conduct PR } & MAT & 3.14 & 0.655 & \multirow{2}{*}{1.072} & \multirow{2}{*}{.285} & \multirow{2}{*}{0.165} \\
\hline & MEd & 3.02 & 0.781 & & & \\
\hline \multirow{2}{*}{ Q6: Support by my colleagues would help me conduct PR } & MAT & 3.01 & 0.712 & \multirow{2}{*}{0.954} & \multirow{2}{*}{.342} & \multirow{2}{*}{0.136} \\
\hline & MEd & 2.91 & 0.759 & & & \\
\hline \multirow{2}{*}{ Q7: I am more likely to conduct PR if I can collaborate with my colleagues } & MAT & 3.27 & 0.796 & \multirow{2}{*}{0.888} & \multirow{2}{*}{.376} & \multirow{2}{*}{0.135} \\
\hline & MEd & 3.16 & 0.825 & & & \\
\hline
\end{tabular}

ES: effect size.

TABLE 4: Comparison of students' responses to the competency questions broken down by degree program (MAT: $N=79 ;$ MEd: $N=97)$.

\begin{tabular}{|c|c|c|c|c|c|c|}
\hline Question & Program & Mean & SD & $t$ value & $P$ value & ES \\
\hline \multirow{2}{*}{ Q8: I can identify and pose research questions } & MAT & 3.19 & 0.662 & \multirow{2}{*}{0.641} & \multirow{2}{*}{.522} & \multirow{2}{*}{0.103} \\
\hline & MEd & 3.12 & 0.696 & & & \\
\hline \multirow{2}{*}{ Q9: I can review and synthesize existing research } & MAT & 3.01 & 0.809 & \multirow{2}{*}{1.347} & \multirow{2}{*}{.180} & \multirow{2}{*}{0.195} \\
\hline & MEd & 2.86 & 0.736 & & & \\
\hline \multirow{2}{*}{ Q10: I can plan research studies } & MAT & 2.72 & 0.767 & \multirow{2}{*}{-0.190} & \multirow{2}{*}{.850} & \multirow{2}{*}{-0.028} \\
\hline & MEd & 2.74 & 0.681 & & & \\
\hline \multirow{2}{*}{ Q11: I can design appropriate data collection tools } & MAT & 2.72 & 0.715 & \multirow{2}{*}{0.279} & \multirow{2}{*}{.781} & \multirow{2}{*}{0.041} \\
\hline & MEd & 2.69 & 0.741 & & & \\
\hline \multirow{2}{*}{ Q12: I can select existing data collection tools, when available } & MAT & 2.87 & 0.822 & \multirow{2}{*}{0.982} & \multirow{2}{*}{.328} & \multirow{2}{*}{0.148} \\
\hline & MEd & 2.75 & 0.804 & & & \\
\hline \multirow{2}{*}{ Q13: I can organize and analyze data I collect } & MAT & 2.96 & 0.912 & \multirow{2}{*}{0.763} & \multirow{2}{*}{.447} & \multirow{2}{*}{0.108} \\
\hline & MEd & 2.87 & 0.759 & & & \\
\hline \multirow{2}{*}{ Q14: I can interpret the findings from the data I collect } & MAT & 2.90 & 0.871 & \multirow{2}{*}{0.694} & \multirow{2}{*}{.641} & \multirow{2}{*}{0.112} \\
\hline & MEd & 2.81 & 0.741 & & & \\
\hline \multirow{2}{*}{ Q15: I can describe the study and its findings in an oral or written report } & MAT & 3.01 & 0.824 & \multirow{2}{*}{0.467} & \multirow{2}{*}{.641} & \multirow{2}{*}{0.066} \\
\hline & MEd & 2.96 & 0.706 & & & \\
\hline
\end{tabular}

ES: effect size.

used in this collaborative process. The demands of first year teaching, the local environment's constraints, and the overriding survival mindset of a beginning teacher made it unlikely that Scott would conduct a formal action research. Scott was coming from the idealistic expectations of what it means to be a teacher and found himself in a chaotic setting, where special education classes appeared to be on the academic and monetary fringes. The goal was to embrace inquiry to enable Scott to gain confidence in his ability to have control over his work and become more proactive in dealing with his particular challenging situation. This, together with no existing curriculum, lack of instructional sources, and poor administrative support, made the first year a time of dissonance and confusion and provided ample room for anxiety and a sense of lack of control.
Feeling at loss during his first year of teaching, Scott somewhat naively assumed that graduate studies would teach the future teachers precisely "how to teach." His impression that what he experienced during the coursework was too "theoretical" signals to us his anxiety around the continuity of interactions between thinking and doing, between reflection and action, and between knowledge and the good to be served by what is produced by that knowledge [38]. In Scott's words:

Well, I viewed it as something very helpful for the university to consider as having some kind of mentoring relationship with new teachers, because a lot of what we experienced in this program was theoretical and it wasn't practical. There was no 
mentoring, no... hardly any support as far as to how to teach, so you're thrown into a new situation that says, teach all these subjects, and so with [instructor] she could watch what I was doing in those particular subjects and make very positive suggestions about how to try to address different ways of teaching, which we never did in the special education program. .... It gets so academic that... it's...

As a shaky beginner, who is yet to learn from his own trials and errors the meaning of "reflection in action," Scott seemed to embody what van Manen [39] described as a usual malady that new teachers have to endure:

But it is not uncommon that, in spite of this excellent preparation, great frustration is encountered: now, facing the students, the new teacher finds, to his or her disillusionment, that all this planning still falls short of what is required by the classroom reality. And, somehow, the hard-won knowledge base of subject matter, teaching skills, educational theories, and curriculum programs still does not live up to the demands of the pedagogical life in the classroom. (Section 2, para. 2)

Having only begun to develop his ability to distance himself from stressful situations and observe and reflect on his role as part of the ever-changing pedagogical context, it is not surprising that Scott saw this research project first and foremost as a mentoring relationship between him and his former research class instructor. The focus of the collaboration was not to induct Scott into action research but rather to help him, a novice, experience the practical advantages of integrating inquiry into practice:

Through observation and discussions, I realized students did not participate in silent reading periods even though I had a variety of books at their reading levels in the classroom. What was missing? What could be done to stimulate their involvement in reading? [Instructor] came up with the idea of finding comics based on popular TV series... I also worked with her in putting together simple questions and behavior assessments for each day that the students read. To my surprise, students picked out the comics or books and read them for approximately 20 minutes for at least 3-4 days (over a 6-7 day span of time). Did this prove anything? Not really. However, I think it was a very useful exercise. If students do not read due to a variety of factors (video games, TV, computer usage, inability to read well), comic books are a good starting point. Through interest inventories, one can figure out what types of TV, books, movies, and so forth, that students like. I'd continue to conduct this type of survey of students at the beginning of the year. I'd work collaboratively with other teachers and the principal to order easy reading books or books on tape (or look at online resources if more computers could be placed in the classroom) to encourage independent reading.

Though Scott appreciated the richness and variety of experiences which the engagement in collaborative action research brought, it is clear that from Scott's perspective, classroom inquiry was embraced because it seemed to have efficacy in his particular circumstances. The experience suggests action research will gradually empower the novice teachers by enabling them to evaluate the effectiveness of their teaching strategies, explore which approach best suits them, and give them a sense of control over their own educational arena.

Scott's experience contradicts the literature on teachers' research that accentuates research done by teachers, for teachers. He retells the situations when the university researcher generated the ideas that he adopted; certainly, modifying them along the way, but following the lead nevertheless. It should be acknowledged then that even the teachers who are willing to undertake this task could feel unprepared, finding themselves "in the midst of it," wanting to rely on a more supportive figure-be it a school administrator, mentor, or university researcher-that troubles sometimes uncritical and idealistic approach to practitioner research.

5.4. Action Research as a Way of "Getting Ahead". Unlike Scott, Wendy came to this research from an economically well off school district. She works in a school that serves predominantly white middle-class students, with her classes being described as "very compliant and fairly respectful." Unlike Scott, she has worked with a plenty of mentors, ranging from her principal, mentors visiting her school and working closely with different grade, and content area teachers as well as district-level mentors. Wendy jokes that, "In my school, I felt like I got mentored to death."

Although a beginning teacher, it was apparent to her instructor that Wendy was drawn to research and was ready to develop and implement her action plan in her classroom. In her words:

I think part of it [doing action research] is narrowing it down and helping people realize that no, we're not expecting you to do a Proctor \& Gamble-sized research project, that you could have only one to three students that you are looking at. (...) I know I was e-mailing [instructor], 'coz I had her before, asking, e-mail me your syllabus, what do I have to do, what do I have to get ready? Almost like a pre-prepped packet of like, if you're going to take this class, here are some things you need to start thinking about, here's what you need to have access to. Because you come in on that first day and you're already behind the eight ball. I knew, because I had [instructor], I knew I could email her and I signed up with my partner. I came in and I'm like, I'm ready to go (laughs), give me a syllabus, what do I need to have, here's what we're 
thinking as a topic. So I mean, we hit the ground running.

Wendy did not need her research classes' instructor in a role of a mentor; her instructor was rather a facilitator in the research process. The two of them chose the topic of homework, which was of interest to both of them. Together they created a survey and administered it to Wendy's students. Although the instructor volunteered to enter the surveys' data, they reflected on and analyzed the data together, looking for insights into middle-school students' attitudes toward homework and implications and practical suggestions for Wendy.

While administrative support plays a significant role in shaping up the teacher-researcher, Wendy's personality and the way she sees her professional responsibilities could be the factor that makes or breaks the teacher-researcher. This is how Wendy sees it:

I'm very high administratively because once you get behind the eight ball, everything else goes downhill. So I'll put it this way: in the two-week period over Christmas break, I planned 12 weeks of both my math curricula. I totally killed myself over the Christmas break planning my math, because I knew I was taking this research project and it would go to spring break. So during those two weeks I planned all my math, so I did not have any math or quizzes that I had to make up. And I got that off my plate because I knew there'd be stuff with research that would pop up.

A couple of times during the focus group interview, Wendy used the phrase of not "getting behind the eight ball." The previous excerpt and a suggestion for the research classes instructors to distribute the complete course material before the terms starts, so that those students who are interested in doing research can "get ahead," reflect Wendy's approach to research and teaching. It also signals to us the seamless transition between the two and our hope that this teacher's practice will be further infused with action research ideas.

5.5. Research as Uncovering of a Reflective Teacher. Ana decided to take part in this research project, not knowing for certain if what she has been doing in her classroom fitted the idea of action research. And yet, since she volunteered to be observed, her instructor's assumption was that something was going on in her classroom that could benefit both Ana and her students. This is now she described her research activities at the beginning of the school year:

It's just... I do not know how to explain it, really. I'm not sure, it's just kind of a... informally in my head. I'm assessing, alright what's he getting from this? Why is it keep happening? It's because he's getting what he wants alright, and just kind of saying, well now what can I have him do that he's going to.. it's behavior modeling, that's what it really is. What can I get him to do that's a good thing that he's going to get the same...
Ana struggles here with the meaning and language. What is it that she is actually doing in the classroom? Thinking mostly about her African American boys who are diagnosed with either behavior or emotional disorder, sometimes as early as in kindergarten, Ana is trying to define this "reflection in action," when she needs to decide in the moment how to respond to a child who refuses to read, or tears down his homework, or seemingly cannot stop laughing or fidgetingall of which was observed in her classroom. van Manen's [39] insight is helpful here:

One could even say that, ironically, in the active
or dynamic situation of teaching cannot help but
be "unreflective" in the curious sense that the
classroom teacher must constantly act on the spot
and cannot step back and postpone acting in
order to first reflect on the various alternatives
to this action and consequences of the various
alternatives. (Section 1, para. 8)

Ana is regarded as a "good teacher" in her school, but the initial interviews were full of unfinished thoughts and difficulties in describing what makes her a "good teacher" or what constitutes her practice. The next classroom episode and the conversation that followed illustrate the gradual shift in Ana's awareness. On one Friday in the spring that seemed particularly long, the following scene occurred during social science period:

The testing season starts next week. Ana does not want to introduce a new book chapter this Friday. Instead, the students are given a chance to finish the work from previous classes. The classroom is quiet and students look lulled, their eyes down at their worksheets, but I cannot tell whether they are working or about to fall asleep, as Anthony does look like he is taking a nap. Ana notices this as well, her eyebrows slightly raised as we exchange glances, but she says nothing. Suddenly, Joshua stands up, walks up to the door and closes it, then turns around and begins to dance. Ana looks at him puzzled, he stops. "You've got some stuff to work on," she says, her voice calm. "Yes," Joshua replies, but keeps moving around the desks, humming. "Get some stuff out and start working, please." As suddenly as he began, Joshua ends his dance as sits across Anthony. "Why aren't you doing any work?" Ana asks Antony. He raises his head and tearing down his worksheet, tells Joshua that is it okay if he gets an " $F$ " and repeats the 6th grade. Then he covers his head with a jacket, the hood entirely covering his face. The class is growing even quieter. All eyes are on Ana. She pulls up a chair, sits next to Antony and talks to him, almost whispering. From where I sit, I cannot hear a word. Field notes, March, 2007.

A teacher has a choice here: to name Antony's and Joshua's behavior as disruptive and to take action by chiding and sending students to the principal's office, or being paralyzed 
by all this and dismissing boys as "they just won't do the work." A teacher could also do what Ana chose to do: understand her students' behavior and respond to it carefully and thoughtfully rather than react to it. This is what she told her instructor about Joshua's movements that occurred many times during class observations:

\begin{abstract}
He's a quirky 11-year old boy, you cannot put him at a desk all day and expect he's gonna be OK. It's just unrealistic, you know. I get antsy when I go to a conference and I'm sitting all day, and I'm moving around, so how can I expect an 11-yearold boy to do it? So, I mean - - And with him, I've, I've gotten to the point with him too where I can tell some of it is because he needs to move; some of it is because he's looking for attention, and if he does not get it, he gets the movement out of his system and comes back to what he needs to do.
\end{abstract}

Ana refuses to adultify Black boys $[40,41]$ and see a developmental phase as a sign of inevitable future troublesome behavior (before the school year started Ana had been warned by some of her colleagues that her boys were "little thugs."). The fact that three months into this research Ana decided to enroll into a doctoral class on race, ethnicity, and education, possibly contributed to her new awareness. She is also trying to uncover the reason for classroom disruptions. Why do they happen and can a BD label help a teacher understand her students? At the end of the school year, Ana is more eloquent in her description of relationship between teaching and research. This is how she described it:

And to be perfectly honest, this is the first year that I felt as if I was actually accomplishing anything in my classroom. It took a couple of years....Yeah, actually this came in a lot, the fact that, in the back of my head, there was someone in my room who was observing what I was doing. And whether or not it was a judgmental-type of observing wasn't the point. It was... It made me think about what I was doing, how I was going to react to this, what sort of strategies could I use to make these kids pay attention and get them to do their work and get them to understand what they were doing, the more I thought about it, by the end of the year, it was second nature and I wasn't thinking about it anymore. (...) This year was absolute insanity in my classroom. I'm still shocked and appalled that it was like it was. The whole eight subjects in a six period thing was just... I'm still trying to wrap my brain around it. And now, in the middle of July, it's been over for more than a month. Had I not had built in your coming in, [instructor], where you were observing, and then we were discussing what was going on in the classroom, I wouldn't have reflected at all this year. I just wouldn't have had the time to do it.

Ana most likely downplays her abilities when claiming that her fourth year in the classroom was the first one when something was accomplished. We would interpret this differently: this feeling of success did not spring out of nowhere; her graduate studies accompanied with personal and professional maturation contributed to this sense of accomplishment. Her thinking about teaching and research has shifted as well as her more nuanced language that describes the process.

And while Scott, as a brand new teacher, sees theory and practice and teaching and research as separate, Ana is arriving to the point where, in the words of Schwandt [42] "acting and thinking, practice and theory, are linked in a continuous process of critical reflection and transformation" (page 191). She sees it this way:

It can be as much an informal process as a formal-this is what my goal is, this is how I'm gonna test it. That was the thing that I mainly got out of the research classes that I took here, was that I honestly did not think that I would have time to do research in my classrooms and so I did not, I did not think. And after I took the class, I realized that what I was doing to try to improve my teaching and try to get my kids to understand is research. That learning about the student and figuring out that this kid's triggers are this, so we're not going to do this because I do not need Johnny to freak out today. This is what this child needs and that in and of itself is research. And the few classes I took in undergrad it was not explained that way. Research was project goal, how do you think it's going to turn out, procedure for how you're going to test it, and it was a long, very drawn... no teacher would have time to do that on a regular basis. That would be an occasional thing. And I think that was what I got the most out of the research classes; it was just the fact that you can do it on a regular basis. It can be small.

\section{Conclusions}

By working with our students towards their understanding and inclusion of the principles of action research into their classrooms, we believe that they were not using action research as a mere technical tool to improve the "smooth operation of schooling" ([28], page 469), but as a mindful and ethical inquiry into their own teaching and the lives of their students in relation to their families, schools, and teachers. To echo Kemmis [28], we do not see our participants as naïve teachers who believe that action research is only a reflection of their own performance. Rather, "practical educational questions about what to teach and how to teach are always themselves a particular expression of more fundamental political questions about which existing patterns of social life ought to be reproduced or transformed" ([43], page 76). As the youngest of three teachers, Ana has begun to question her assumptions about the ways that school system in general responds to minority students and how the politics of exclusion trickles down to her own classroom. Three months into the research process, she decided to 
take a doctoral level class on race, ethnicity, and education in order to be initiated in theories and discourses that, at the first glance, could not be easily translated into day-today classroom dynamics. She confirms that to engage in a practice is to be initiated into theories, beliefs, values, and the language that constitute that practice. Therefore, acting and thinking, practice and theory, are linked in a continuous process of self-examination and self-transformation [38].

Wendy and Scott are mature professionals, for whom teaching is the second career. Despite their concerns whether they are "good teachers," their eyes are open to the working of the schools that are presently mostly places that cherish bureaucracy and the "vision of 'the curriculum' as something that has to be variously submitted to, followed, thought, covered, committed to memory, shoved in a drawer, or accounted for in meticulous detail in the practice of teaching young children" ([44] page 227). In such a climate, action research indeed happened behind the closed doors, and we are reluctant to claim that teachers' research practices will dramatically shape the environment in their schools. For that to occur, a systemic change needs to occur first, where both university and local school administration are more attuned to the needs of those interested in this type of collaboration [45]. Schools where the administrators support the efforts of individual teachers and have a genuine appreciation for research, have a chance to bring about school-wide changes. One of the limitations of our study emanates from this realization: while visiting schools, we did not interview the administrators. Our contact with school principals ended upon their approval of our visits, and their perspective is missing.

Each of our participants understood research differently. It could be a mentoring process where the experienced university researcher acts as a collaborator and "helper" who could provide just enough of the push for teachers to develop research on their own. Action research was also seen as a means to grow professionally and personally through the development of various assessment strategies or adoption of a reflective orientation and learning how to become a more culturally responsive teacher. Working together with our students often meant working through their (and our own) dilemmas, insecurities, and fears. What we found is not neatly aligned with the notion of teachers who do research for themselves by themselves. Although the work that teachers do has been well documented, the knowledge claims they attempt to make via action research have been only partial [46] and teachers continue to struggle with the notion that the "mere" description of their practice is considered valid research [47]. We saw then our role as supportive collaborators and colleagues, whose experience, and to a degree, distance-after all, we were not dealing with "our" classrooms-were welcomed by these three teachers. The teachers needed a sounding board, practical suggestions, and reassurance that what they were doing was indeed a legitimate action research. At times when they felt confused or unsure of the value of their inquiry and what it would contribute to their work, we provided our support, encouragement, and appreciation.
Since the systematic inquiry stopped at the time of this writing, we do not know whether these teachers have continued applying the action research principles. We also do not know what happened to other students who completed the survey and left the university. However, based on this study of three dedicated teachers, we do believe that we confirmed that "teacher knowledge is irreducibly mediated by multiple discourses while preserving a commitment to the idea that individual teacher's experience can be a source of novel and useful knowledge" ([48], page 422).

As research classes, university instructors, we conclude that action research courses require a great deal of deliberation on how these courses are developed and taught and how they serve the action research agendas of present and future pre-service and in-service students. Self-study of the pedagogy and curriculum of research courses should allow teacher educators to simultaneously achieve two goals: support pre-service and in-service students as they construct knowledge through their action research, gain meaningful knowledge about education and schooling, and at the same time, to have teacher educators study and critically analyze their own practice, rethink their assumptions, and construct and reconstruct their action research courses.

\section{References}

[1] C. Hendricks, Improving Schools through Action Research: A Comprehensive Guide for Educators, Pearson, Boston, Mass, USA, 2nd edition, 2009.

[2] W. Carr and S. Kemmis, Becoming Critical: Education, Knowledge and Action Research, Falmer Press, London, UK, 1986.

[3] A. P. Johnson, A Short Guide to Action Research, Pearson, Boston, Mass, USA, 3rd edition, 2011.

[4] C. A. Mertler, Action Research: Teachers as Researchers in the Classroom, Sage, Thousand Oaks, Calif, USA, 3rd edition, 2012.

[5] S. Kemmis and R. McTaggart, "Participatory action research: communicative action and the public sphere," in Strategies of Qualitative Inquiry, N. K. Denzin and Y. S. Lincoln, Eds., pp. 271-330, Sage, Thousand Oaks, Calif, USA, 3rd edition, 2008.

[6] M. L. Holly, J. M. Arhar, and W. C. Kasten, Action Research for Teachers: Traveling the Yellow Brick Road, Allyn \& Bacon, Boston, Mass, USA, 3rd edition, 2009.

[7] S. E. Noffke, "Professional, personal, and political dimensions of action research," in Review of Research in Education, M. Apple, Ed., vol. 22, pp. 305-343, American Educational Research Association, Washington, DC, USA, 1997.

[8] M. Cochran-Smith and S. Lytle, Inquiry as Stance: Practitioner Research in the Next Generation, Teachers College Press, New York, 2009.

[9] S. C. Bauer and S. D. Brazer, Using Research to Lead School Improvement: Turning Evidence into Action, Sage, Thousand Oaks, Calif, USA, 2012.

[10] J. McNiff and J. Whitehead, All You Need to Know About Action Research, Sage, Thousand Oaks, Calif, USA, 2nd edition, 2011.

[11] G. E. Mills, Action Research: A Guide for the Teacher Researcher, Merrill-Prentice Hall, Upper Saddle River, NJ, USA, 3rd edition, 2010.

[12] D. K. Phillips and K. Carr, Becoming a Teacher through Action Research, Routledge, New York, NY, USA, 2nd edition, 2010. 
[13] E. Stringer, Action Research in Education, Prentice-Hall, Upper Saddle River, NJ, USA, 2nd edition, 2008.

[14] K. Zeichner, Teacher Education and the Struggle for Social Justice, Routledge, New York, NY, USA, 2009.

[15] M. F. Connelly and J. D. Clandinin, Narrative Inquiry: Experience and Story in Qualitative Research, Jossey-Bass, San Francisco, Calif, USA, 2000.

[16] D. Pushor and D. J. Clandinin, "The interconnections between narrative inquiry and action research," in The SAGE Handbook of Educational Action Research, S. E. Noffke and B. Somekh, Eds., pp. 290-299, Sage, Thousand Oaks, Calif, USA, 2009.

[17] J. Kitchen and D. Stevens, "Action research in teacher education: two teacher-educators practice action research as they introduce action research to preservice teachers," Action Research, vol. 6, pp. 7-28, 2008.

[18] J. N. Price and L. Valli, "Preservice teachers becoming agents of change," Journal of Teacher Education, vol. 56, pp. 57-72, 2005.

[19] T. C. Rock and B. B. Levin, "Collaborative action research projects: enhancing preservice teacher development in professional development schools," Teacher Education Quarterly, vol. 29, pp. 7-21, 2002.

[20] K. M. Zeichner and J. M. Gore, "Using action research as a vehicle for student teacher reflection: a social reconstruction approach," in Educational Action Research: Becoming Practically Critical, S. E. Noffke and R. B. Stevenson, Eds., pp. 13-30, Teacher College Press, New York, NY, USA, 1995.

[21] K. Kinser, "The utility of educational action research for emancipatory change," Action Research, vol. 8, pp. 171-189, 2010.

[22] G. Fenstermacher, "The knower and the known: the nature of knowledge in research on teaching," in Review of Research in Education, L. Darling-Hammond, Ed., vol. 20, pp. 356, American Educational Research Association, Washington, DC, USA, 1994.

[23] M. Huberman, "Moving mainstream: taking a closer look at teacher research," Language Arts, vol. 73, pp. 124-140, 1996.

[24] D. F. Labaree, "The peculiar problems of preparing educational researcher," Educational Researcher, vol. 32, pp. 13-22, 2003.

[25] C. Glesne, "Yet another role? The teacher as researcher," Action in Teacher Education, vol. 13, pp. 7-13, 1991.

[26] K. Goodnough, "Teacher development through action research: a case study of an elementary teacher," Action in Teacher Education, vol. 22, pp. 37-46, 2001.

[27] E. McDaniel, "Collaboration for what? Sharpening the focus," Action in Teacher Education, vol. 10, pp. 1-8, 1988.

[28] S. Kemmis, "Participatory action research and the public sphere," Educational Action Research, vol. 14, pp. 459-476, 2006.

[29] M. Q. Patton, Qualitative Research \& Evaluation Methods, Sage, Thousand Oaks, Calif, USA, 4th edition, 2008.

[30] I. Ginns, A. Heirdsfield, B. Atweh, and J. J. Watter, "Beginning teachers becoming professionals through action research," Educational Action Research, vol. 9, pp. 111-120, 2001.

[31] B. Tedlock, "Ethnography and ethnographic representation," in Strategies of Qualitative Inquiry, N. K. Denzin and Y. S. Lincoln, Eds., pp. 151-172, Sage, Thousand Oaks, Calif, USA, 2nd edition, 2008.

[32] G. Kamberelis and G. Dimitriadis, "Focus groups: strategic articulations of politics and inquiry," in Collecting and Interpreting Qualitative Materials, N. K. Denzin and Y. S. Lincoln, Eds., pp. 375-402, Sage, Thousand Oaks, Calif, USA, 3rd edition, 2008.
[33] H. F. Wolcott, Transforming Qualitative Data: Description, Analysis, and Interpretation, Sage, Thousand Oaks, Calif, USA, 1994.

[34] J. W. Creswell, Educational Research: Planning, Conducting, and Evaluating Quantitative and Qualitative Research, Pearson Prentice Hall, Upper Saddle River, NJ, USA, 3rd edition, 2008.

[35] C. Glesne, Becoming Qualitative Researchers: An Introduction, Prentice Hall, Boston, Mass, USA, 4th edition, 2010.

[36] J. Cohen, Statistical Power Analysis for Behavioral Sciences, Routledge Academic, New York, NY, USA, 2nd edition, 1988.

[37] C. W. Mills, The Sociological Imagination, Oxford University Press, New York, NY, USA, 1959.

[38] T. A. Schwandt, Dictionary of Qualitative Inquiry, Sage, TThousand Oaks, Calif, USA, 2nd edition, 2004.

[39] M. van Manen, "On the epistemology of reflective practice," Teachers and Teaching, vol. 1, pp. 33-50, 1994, http://www .phenomenologyonline.com/max/articles/epistpractice.html.

[40] G. A. Duncan, "Beyond love: a critical race ethnography of the schooling of adolescent Black males," Equity \& Excellence in Education, vol. 35, no. 2, pp. 131-143, 2002.

[41] A. A. Ferguson, Bad Boys: Public Schools in the Making of Black Masculinity, University of Michigan Press, Ann Arbor, Mich, USA, 2000.

[42] T. A. Schwandt, "Three epistemological stances for qualitative inquiry: interpretivism, hermeneutics, and social constructionism," in Handbook of Qualitative Research, N. K. Denzin and Y. S. Lincolon, Eds., pp. 189-214, Sage, Thousand Oaks, Calif, USA, 2nd edition, 2000.

[43] W. Carr and S. Kemmis, "Educational action research: a critical approach," in The SAGE Handbook of Educational Action Research, S. E. Noffke and B. Somekh, Eds., pp. 74-84, Sage, Thousand Oaks, Calif, USA, 2009.

[44] D. W. Jardine, S. Friesen, and P. Clifford, Curriculum in Abundance, Lawrence Erlbaum Associates, Mahwah, NJ, USA, 2006.

[45] S. E. Efron, M. Miskovic, and R. Ravid, "School-university collaboration as mutual professional development," in Collaboration in Education, J. J. Slater and R. Ravid, Eds., pp. 73-79, Routledge, New York, NY, USA, 2010.

[46] S. E. Noffke, "Research relevancy or research for change?" Educational Researcher, vol. 37, pp. 429-431, 2008.

[47] S. Bartlet and D. Burton, "Practitioner research or descriptions of classroom practice? A discussion of teachers investigating their classrooms," Educational Action Research, vol. 14, pp. 395-405, 2006.

[48] J. Rosiek and B. Atkinson, "Bridging the divides: the need for a pragmatic semiotics of teacher knowledge research," Educational Theory, vol. 55, pp. 421-442, 2005. 


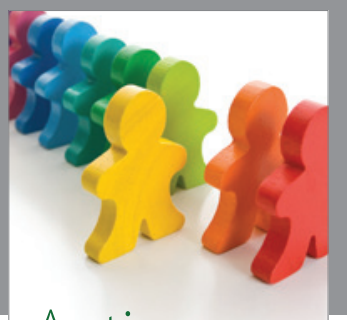

Autism

Research and Treatment
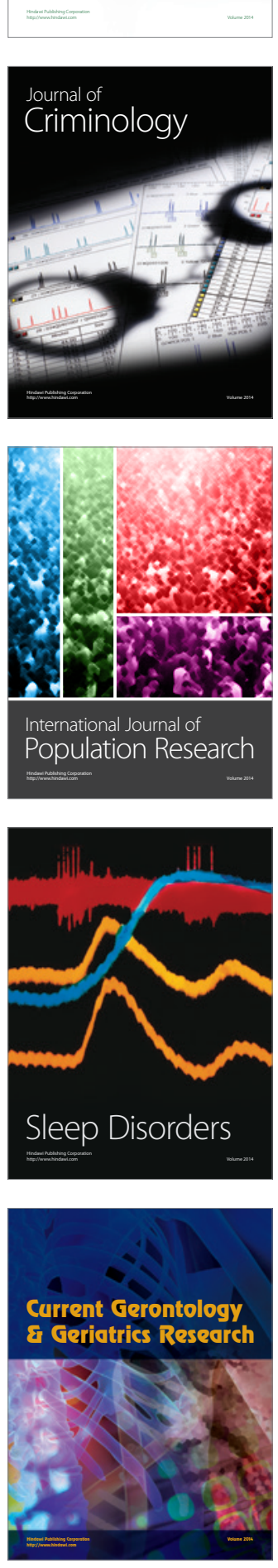
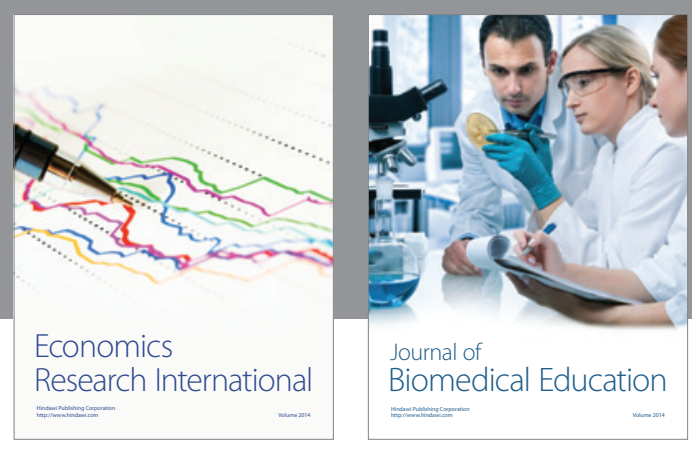

Journal of

Biomedical Education

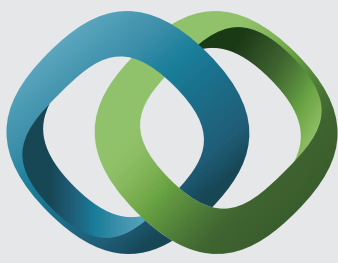

\section{Hindawi}

Submit your manuscripts at

http://www.hindawi.com
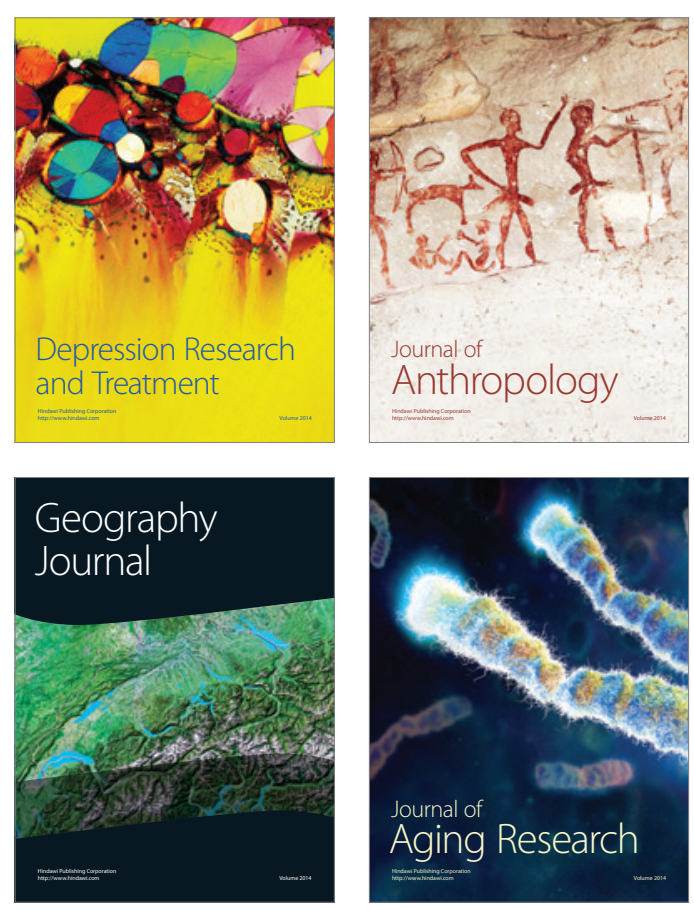

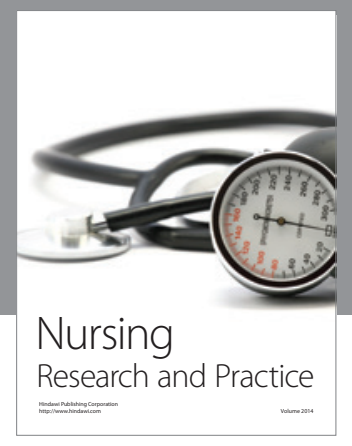

Nursing

Research and Practice

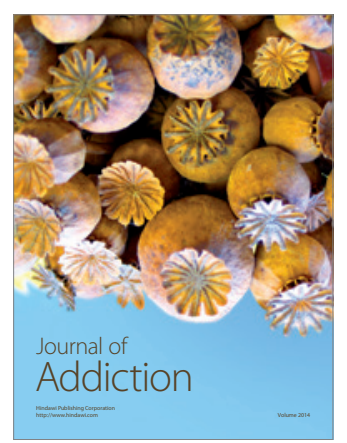

Child Development

Research

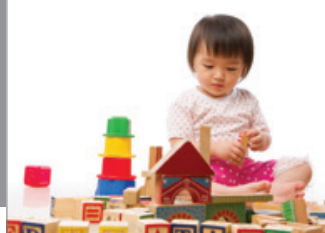

迥
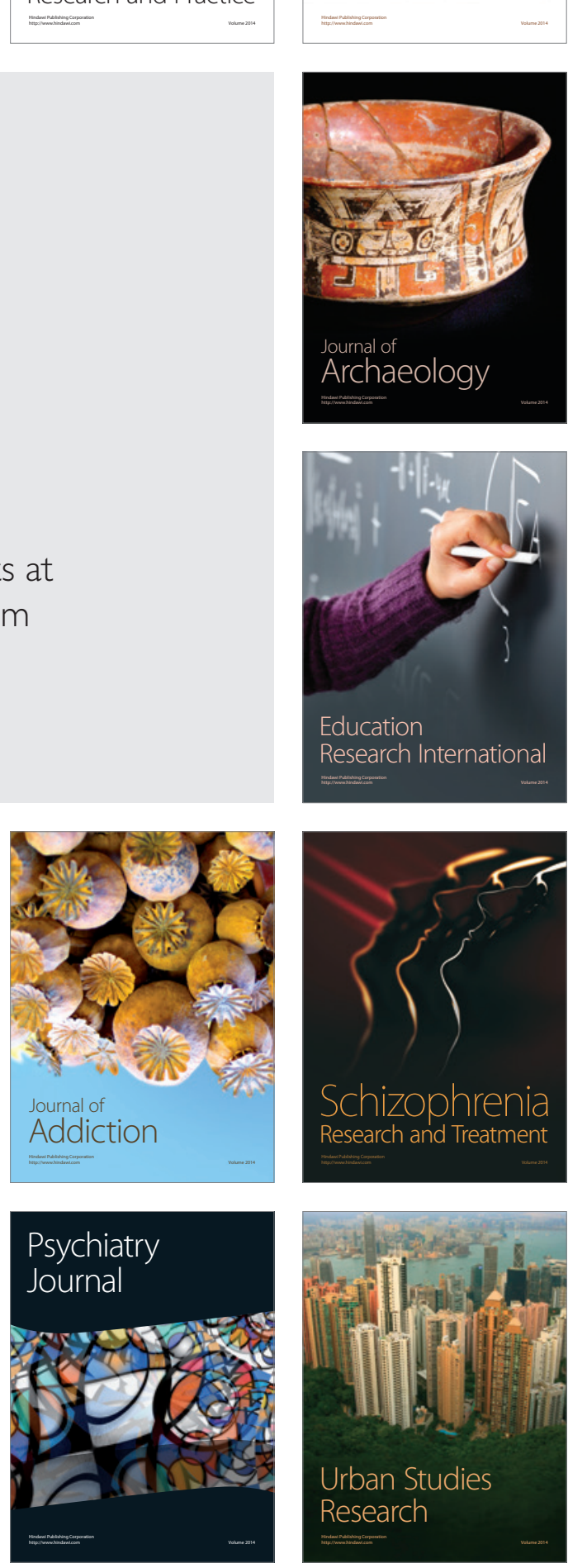